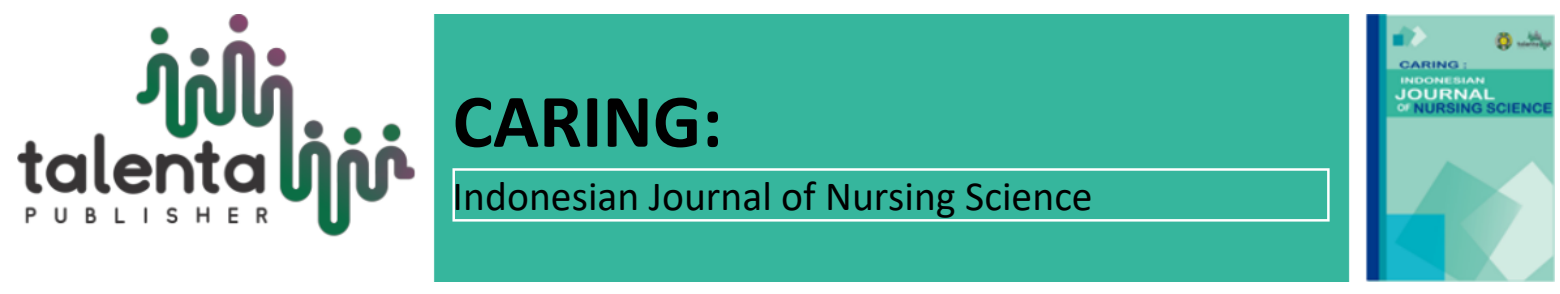

\title{
Post Partum's Knowledge about Breast Care at Niar Patumbak Clinic
}

\author{
Indrawati $^{1}$, Eqlima Elfira ${ }^{2 *}$ \\ ${ }^{1}$ Polytechnic Health of Medan, Indonesia \\ ${ }^{2}$ Faculty of Nursing, University Sumatera Utara, Medan - Indonesia
}

\begin{abstract}
Woman tend to treat the breast during the puerperium (breastfeeding period) to streamline the breastfeeding process. It's due to maximize the breast function as the only producer of breast milk, and found good for newborns. This study aims to determine the knowledge of mothers about breast care using a cross-sectional study design. The sampling method used was purposive sampling with a sample size of 41 respondents and the tools used in data collection were questionnaires. The results of this study showed that the majority of mothers with high school education with a focus on taking care of the household had a sufficient level of knowledge in carrying out breast care, around 58,5\% as many as 24 mothers. It is hoped that health workers can further improve education about breast care by frequently providing information such as counseling at health centers or when implementing Posyandu and carrying out cross-sectoral cooperation to increase maternal knowledge about breast care.
\end{abstract}

Keywords: Knowledge, postpartum, mother, breast care, breastfeeding

Received 8 November 2020 | Revised 12 December 2020| Accepted 30 December 2020

\section{Introduction}

Breast milk is the most important baby food especially in the first months of life. Breastfeeding according to WHO is that babies are given breast milk for at least 6 months and provide solid food after the baby is 6 months old or breastfeeding is continued until the child is two years old (Maria Beatrix Tyfani, Ngesti W. Utami, 2017). Based on a survey in Indonesia in 2010, it was found that the exclusive breastfeeding coverage rate was 33.6\%, increasing by $38.5 \%$ in 2011 and 2013 by $30.4 \%$. From the research results, it is said that the production of breast milk is one of the factors that influence is psychological(Rahmi, Romlah, Ramadihina, \& Sari, 2020). The goal of breast care is to stimulate the fluency of breast milk and increase milk production.

*Corresponding author at Jalan Bunga Ncole.

Corresponding e-mail: gayoindrawati@gmail.com

Copyright (C) Published by Talenta Publisher, ISSN: 2580-6769 e-ISSN: 2580-829X

Journal Homepage: https://talenta.usu.ac.id/IJNS 
Breast milk production is influenced by two hormones, namely prolactin, and oxytocin. Prolactin affects the amount of milk production, while oxytocin affects the process of breastfeeding. Factors of mother's age, infant age, husband/family support have nothing to do with breast milk production (Rahmawati \& Prayogi, 2017). The natural process of breastfeeding will make the baby get adequate nutrition and an abundance of love which is useful for their development. During pregnancy, prolactin and placental hormones increase but the ASI usually does not come out because it is still inhabited by high estrogen levels. On the second or third day after delivery, the levels of estrogen and progesterone drop dramatically, so that the influence of prolactin is more dominant and it is at this time that breast milk secretion begins. Breast care can increase milk production and breast care is highly recommended (Rahayuningsih, Mudigdo, \& Murti, 2016). Knowledge is a very important domain for the formation of one's actions (overt behavior). Knowledge is influenced by formal education and very closely related to education, where it is hoped that with higher education, the person will have broader knowledge(Sari \& Ernawati, 2016). The cycle of breastfeeding and pregnancy 1 has been largely ignored by the medical practice where breastmilk can be stored with formula or manufactured products. This is the case in high-income countries, where less than one in five children is breastfed by 12 months of age. For every doubling of the national gross domestic product per person, the prevalence of breastfeeding at 12 months decreased by 10 proportion points. The results of epidemiological and biological studies of the fact that the decision not to breastfeed a child has a major long-term effect on the health, nutrition, and development of children and women's health. Meanwhile, immunological, epigenetic, microbiome, and stem cell studies conducted over the past two decades that shed light on the potential at which breastfeeding can improve outcomes will be followed by other, more interesting findings of the specific, personalized drug that breast milk provides (Victora et al., 2016). The habits carried out in a different culture in carrying out breast care so that the milk produced can meet the needs of the baby. Early initiation of breastfeeding is best done early when the baby is born into the world (Ruth A.Lawrence, 2010). Postpartum mothers with negative early breastfeeding experience were more likely to experience depressive symptoms in the first 2 months. Postpartum mothers with breastfeeding difficulties should be screened for symptoms of depression(Watkins, Meltzer-Brody, Zolnoun, \& Stuebe, 2011). Exclusive breastfeeding for six deficiencies of gastrointestinal infections and helps mothers lose weight and prevent pregnancy but has no long-term impact on allergies, growth, obesity, cognitive abilities, or behavior. Research from studies of two controlled trials and 21 shows that offering exclusive breastfeeding for six months has an advantage over offering exclusive breastfeeding for three to four months followed by offering mixed breast milk (Kramer \& Kakuma, 2002). This is what makes researchers interested in researching breast care in the Niar Patumbak clinic. 


\section{Research Method}

The type of research used is descriptive research, to determine an objective description of a situation. The research design used was cross-sectional. The design is to observe or measure variables once and at the same time. This research was conducted from January to May 2019. The sample is a large part of the population which is expected to represent the population. In this study, the sample is part of the polls by purposive sampling. The number of samples was taken using the Slovin formula with 41 people as the research sample.

$$
n=\frac{N}{1+N\left(e^{2)}\right.}
$$

Information:

$\mathrm{n}=$ sample size

$\mathrm{N}=$ size

population

$\mathrm{e}=$ percent leeway in inaccuracy due to tolerable or desirable sampling errors.

$$
\begin{gathered}
n=\frac{N}{1+N\left(e^{2}\right)} \\
n=\frac{510}{1+510\left(0,15^{2}\right)} \\
n=\frac{510}{12,475} \\
n=40,88
\end{gathered}
$$

Before conducting interviews, respondents were given informed consent followed by questionnaires. Data collected from respondents included age, education, and length of work which were filled in the questionnaire. The questions consist of 20 questions about how the benefits and consequences of not doing breast care that has been given to the respondent. Respondents choose one of the most appropriate answers. The assessment conducted by the researcher if the answer is correct then it is given a score of 1 and if the answer is wrong then it is given a score of 0 . Based on the score obtained by the respondent, the respondent's knowledge is divided into 3, namely, if the respondent answers the correct questions $16-20(76 \%-100 \%)$ then the knowledge good, if the respondent answers 11-15 (56\%-75\%) correctly, the knowledge is sufficient, if the respondent answers the correct question $<11(<56 \%)$ then the knowledge is lacking. Furthermore, the data that has been collected is made in the form of table distribution. 


\section{Results and Discussion}

The result of this study is conducted below:

Table 1. Frequency Distribution of Respondents Post Partum's knowledge about breast care at the Niar Patumbak Clinic

\begin{tabular}{llcc}
\hline & \multicolumn{1}{c}{ Characteristics } & f & \% \\
\hline Age & a. <20 year & 6 & 14,6 \\
& b. 20-35 year & 31 & 75,6 \\
& c. >35 year & 4 & 9,8 \\
Education & No school & 2 & 4,9 \\
& Primary school, & 3 & 7.3 \\
& Junior high school, & 9 & 22,0 \\
& Senior High School & 20 & 48,7 \\
& Diploma / Bachelor & 7 & 17,1 \\
& degree & & \\
Work & & 3 & 7,3 \\
& Government employees & & 65,9 \\
& Housewife & 27 & 26,8 \\
\hline
\end{tabular}

Table 1 showed that based on the age of the majority of respondents, 31 people are 20 - 35 years old (75.6\%), based on the education of the majority of respondents with high school education there are 20 people (44.8\%) the majority of IRT jobs are 27 people $(65.9 \%)$.

Table 2 Distribution of Frequency of Knowledge of Post Partum Mothers about Breast Care Based on Knowledge Level at the Niar Patumbak Clinic

\begin{tabular}{ccc}
\hline Knowledge & $\boldsymbol{f}$ & \% \\
\hline Good & 10 & 24,4 \\
Enough & 24 & 58,5 \\
Less & 7 & 17,1 \\
\hline
\end{tabular}

Table 2. showed that based on the level of knowledge including good knowledge as many as 10 people (24.4\%), sufficient knowledge as many as 24 people (58.4\%), less knowledge as many as 7 people $(17.1 \%)$.

Table 3. Distribution of Frequency of Knowledge of Post Partum Mothers about Breast Care by Age at Niar Patumbak Clinic

\begin{tabular}{ccccccc}
\hline \multirow{2}{*}{ Age } & \multicolumn{6}{c}{ Knowledge } \\
& \multicolumn{2}{c}{ Good } & \multicolumn{2}{c}{ Moderate } & \multicolumn{2}{c}{ Poor } \\
\cline { 2 - 7 } & $\mathbf{n}$ & $\boldsymbol{\%}$ & $\mathbf{n}$ & $\boldsymbol{\%}$ & $\mathbf{n}$ & $\boldsymbol{\%}$ \\
\hline$<20$ year & 2 & 4,8 & 4 & 9,8 & 0 & 0,0 \\
$20-35$ & 7 & 17,4 & 18 & 43,4 & 6 & 14,8 \\
$>35$ year & 1 & 2,5 & 2 & 4,8 & 1 & 2,5 \\
\hline
\end{tabular}


Table 3 showed that of 2 people had moderate knowledge (20.0\%), 4 people had sufficient knowledge (16.7\%), and there was no lack of knowledge (0.0\%). At the age of 20-35 years, 7 people with good knowledge (70.0\%), 18 people (75.0\%) sufficient knowledge, 6 people $(85.7 \%)$ lacking knowledge. At the age of $>35$ years with good knowledge, 1 person (10.0\%), only 2 people $(8.3 \%)$, less 1 person $(14.3 \%)$.

Table 4. Distribution of Frequency of Knowledge of Post Partum Mothers about Breast Care Based on Education at the Niar Patumbak Clinic

\begin{tabular}{|c|c|c|c|c|c|c|c|c|}
\hline \multirow{3}{*}{ Education } & \multicolumn{6}{|c|}{ Knowledge } & \multirow{3}{*}{$\mathrm{n}$} & \multirow{3}{*}{$\%$} \\
\hline & \multicolumn{2}{|c|}{ Good } & \multicolumn{2}{|c|}{ Moderate } & \multicolumn{2}{|c|}{ Poor } & & \\
\hline & $\mathrm{n}$ & $\%$ & $\mathrm{n}$ & $\%$ & $\mathrm{n}$ & $\%$ & & \\
\hline No school & 0 & 0 & 0 & 0 & 2 & 5,0 & 2 & 5,0 \\
\hline Primary school, & 0 & 0 & 0 & 0 & 3 & 7,4 & 3 & 7,4 \\
\hline $\begin{array}{l}\text { Junior high } \\
\text { school, }\end{array}$ & 1 & 2,4 & 6 & 14,6 & 1 & 2,4 & 8 & 19,3 \\
\hline $\begin{array}{l}\text { Senior High } \\
\text { School }\end{array}$ & 2 & 4,8 & 18 & 43,0 & 1 & 2,4 & 21 & 51,2 \\
\hline $\begin{array}{l}\text { Diploma / } \\
\text { Bachelor degree }\end{array}$ & 7 & 17,1 & 0 & 0 & 0 & 0 & 7 & 17,1 \\
\hline
\end{tabular}

Table 4 showed that out of 41 respondents to mothers who did not go to school, none of them had good and sufficient knowledge, 2 people lacked knowledge (28.6\%). In primary school education mothers who have good and sufficient knowledge $(0.0 \%)$, less knowledge is as many as 3 people $(42.9 \%)$. In junior high school education mothers have good knowledge of 1 person (10.0\%), have sufficient knowledge of 6 people (25.0\%), and less knowledgeable 1 person (14.3\%). In high school education mothers who have good knowledge of 2 people (20.0\%), knowledgeable enough 180 people (75.5\%), and less knowledgeable 1 person (14.3\%). There were 7 mothers with good knowledge of Diploma / Bachelor education (70.0\%), who had sufficient knowledge and none.

Table 5. Distribution of Frequency of Knowledge of Post Partum Mothers about Breast Care by occupation at the Niar Patumbak Clinic

\begin{tabular}{|c|c|c|c|c|c|c|c|c|}
\hline \multirow{3}{*}{ Work } & \multicolumn{6}{|c|}{ Knowledge } & \multirow[b]{3}{*}{$\mathbf{n}$} & \multirow[b]{3}{*}{$\%$} \\
\hline & \multicolumn{2}{|c|}{ Good } & \multicolumn{2}{|c|}{ Enough } & \multicolumn{2}{|c|}{ Less } & & \\
\hline & n & $\%$ & $\mathbf{n}$ & $\%$ & $\mathbf{n}$ & $\%$ & & \\
\hline $\begin{array}{l}\text { Government } \\
\text { employees }\end{array}$ & 3 & 7,3 & 0 & 0 & 0 & 0,0 & 3 & 7,3 \\
\hline Housewife & 4 & 9,9 & 17 & 41,2 & 6 & 14,7 & 27 & 65,9 \\
\hline $\begin{array}{l}\text { Private } \\
\text { employees }\end{array}$ & 3 & 7,3 & 7 & 17,2 & 1 & 2,4 & 11 & 26,8 \\
\hline
\end{tabular}

Table 5 showed that of the 41 respondents, the majority of mothers were working as well-informed housewives as many as 4 people (40.0\%), sufficient knowledge was 17 people $(70.8 \%)$, and less knowledgeable was 6 people $(85.7 \%) \%) .3$ mothers work as well-knowledgeable civil servants $(30.0 \%)$, with sufficient and insufficient knowledge. 3 mothers work as well-informed entrepreneurs (30.0\%), 7 people (29.2\%) have sufficient knowledge, 1 person (14.3\%) lacks knowledge. 
The knowledge of post-partum mothers about breast care as shown in Table 1 illustrates that based on the highest level of knowledge, 24 people (58.5\%) had sufficient knowledge, while 10 mothers who had good knowledge (24.4\%) and less knowledge were 7 people (17.1\%) from the table above it can be concluded that the lack of knowledge of mothers about breast care is because the majority of mothers do not go to school 2 people (4.9\%), where low education makes it difficult for mothers to receive information about breast care either from other people and from health workers, on the other hand, if maternal education is high, it will be easier for mothers to get information about breast care.

According to Maritalia (2012), age will affect the ability and self-readiness of the mother to go through childbirth and breastfeeding. Mothers who are 40 years old will be different in going through the postpartum period and breastfeeding compared to mothers who are 18 years old. The results of this study are in line with Luvita Sari, Susi Ernawati (2015) entitled the knowledge of third-trimester pregnant women about breast care at the Pratama Bina Sehat Kasihan clinic, Bantul, Yogyakarta, showing that most of the respondents were aged 20-35 years, namely 50 respondents $(70,4 \%)$, with secondary education as many as 38 respondents (53.5\%), not working as many as 43 respondents $(60.6 \%)$ and having a multiparity parity of 34 respondents $(47.9 \%)$. The results of the research conducted by researchers showed that the majority of respondents were 20-35 years old and had sufficient knowledge of 18 respondents (75.0\%). At this age, a person is at a good level of mental development and the experience gained is also quite a lot, so that it will affect their insight and knowledge and thus they can be able to understand information which ultimately has an impact on how to apply the information they have received.

Age is one of the important things in influencing one's knowledge. The higher the age of a person, the higher the level of knowledge, and this is obtained from experience. This will affect the actions a person will take (Sari \& Ernawati, 2016)

The results of this study are in line with Luvita Sari, Susi Ernawati (2015) showing that in the age group $<20$ years most of them have moderate knowledge with 4 respondents $(57.1 \%)$, in the 20-35 year age group most of them have moderate knowledge with the number of 34 respondents (68.0\%), and in the age group > 35 years, most of them have moderate and high knowledge with a total of 6 respondents (42.9\%). The mother's age determines maternal health and is related to the condition of pregnancy, childbirth, and childbirth and how to care for and breastfeed her baby. The increasing age, the better the presentation of knowledge because it is caused by the low access to information and insights. The results of the research conducted by researchers showed that the majority of respondents who had basic education had less knowledge of as many as 5 respondents (71.5\%). Education is a very important thing that must be taken by every individual, because the higher education a person takes, the easier it will be for someone to receive and absorb information so that the person's knowledge will be better. It is clear that with high knowledge, insight, and efforts to seek information will be broader because people who have basic secondary and tertiary education are easier to understand and understand the information they receive when compared to respondents with lower education (Sari Luvita, Ernawati Sari 2015 ).

The results of this study are in line with Luvita Sari, Susi Ernawati (2015) showing that in the basic education group most of them have moderate knowledge with 16 respondents $(72.7 \%)$, in the secondary 
education group most of them have moderate knowledge with 24 respondents $(63,2 \%)$, and in the higher education group most of them had moderate and high knowledge with a total of 4 respondents (36.4\%). It is clear that with high knowledge the insight and effort to seek information will be wider because people who have basic secondary and tertiary education are easier to understand and understand the information they receive when compared to respondents with lower education. Work is the main or daily routine task of the respondent whether it makes money or not. The results of the research conducted by researchers showed that the majority of respondents worked as housewives and had sufficient knowledge of 17 (70.8\%) and less than 6 people (85.7\%). 3 respondents work as civil servants and have good knowledge, this is because working mothers will find many friend relations so that they can enrich more insight and knowledge than mothers who do not work, besides that someone who works tends to more easily receive information to increase their knowledge. about breast care. Work can also affect knowledge of daily behavior. Work is an activity that is carried out daily. Where all fields of work generally require social relationships and relationships with good people, everyone must be able to get along with other people, everyone has to hang out with colleagues and relate to superiors, so the more information is obtained to increase one's knowledge. Work can describe the level of a person's life because it can affect some aspects of a person's life, including health care.

\section{Conclusion}

The study concludes that postpartum mothers will experience a breastfeeding process which requires how the treatment process is influenced by stimulation of breast milk production and the things that affect postpartum mothers in initiating early breastfeeding.

\section{Acknowledgment}

The authors would like to thank the respondents for all the valuable data provided in this research.

\section{Conflict of Interest}

There is no conflict of interest in this research result

\section{REFERENCES}

[1] Kramer, M. S., \& Kakuma, R. (2002). The optimal duration of exclusive breastfeeding. Tropical Doctor, 32(1), 62-63. https://doi.org/10.1002/14651858.cd003517.pub2

[2] Maria Beatrix Tyfani, Ngesti W. Utami, S. S. (2017). THE RELATIONSHIP BETWEEN IMPLEMENTATION OF BREAST CARE AND BREASTFEEDING SMOOTHNESS ON POSTPARTUM MOTHERS IN TLOGOMAS VILLAGE, LOWOKWARU MALANG. In $\begin{array}{lllll}\text { Nursing News (Vol. } & 2 \text { ). } & \text { Retrieved }\end{array}$ https://publikasi.unitri.ac.id/index.php/fikes/article/view/179

[3] Rahayuningsih, T., Mudigdo, A., \& Murti, B. (2016). Effect of Breast Care and Oxytocin Massage on Breast Milk Production: A study in Sukoharjo Provincial Hospital. Journal of Maternal and Child Health, 01(02), 101-109. https://doi.org/10.26911/thejmch.2016.01.02.05 
[4] Rahmawati, A., \& Prayogi, B. (2017). Analisis Faktor Yang Mempengaruhi Produksi Air Susu Ibu (ASI) Pada Ibu Menyusui Yang Bekerja. Jurnal Ners Dan Kebidanan, 4(2), 134-140. Retrieved from https://media.neliti.com/media/publications/232701-analysis-of-factorsaffecting-breastmilk-a8fa2353.pdf

[5] Rahmi, J., Romlah, S. N., Ramadihina, A. R., \& Sari, I. P. (2020). Pengaruh Perawatan Payudara Terhadap Kelancaran Asi Dan Tingkat Kecemasan Pada Ibu Nifas. Edu Masda, 4(1), $49-55$.

[6] Ruth A.Lawrence, R. M. L. (2010). Breastfeeding: A Guide for the Medical Professional - Ruth A. Lawrence, Robert M. Lawrence - Google Books. Retrieved December 12, 2020, from Elsevier Health Sciences website: https://books.google.co.id/books?hl=en\&lr=\&id=c4BnozBW3EMC\&oi=fnd\&pg=PP1\&dq=br eastfeeding\&ots=ePsSsFcC2s\&sig=BvAi6u6pdcX1vD-

FCxsjkDXv42g\&redir_esc $=\mathrm{y} \# \mathrm{v}=$ onepage $\& \mathrm{q}=$ breastfeeding $\& \mathrm{f}=$ false

[7] Sari, L., \& Ernawati, S. (2016). Pengetahuan Ibu Hamil Trimester III tentang Perawatan Payudara di Klinik Pratama Bina Sehat Kasihan, Bantul, Yogyakarta. Jurnal Ners Dan Kebidanan Indonesia, 3(1), 26. https://doi.org/10.21927/jnki.2015.3(1).26-32

[8] Victora, C. G., Bahl, R., Barros, A. J. D., França, G. V. A., Horton, S., Krasevec, J., ... Richter, L. (2016, January 30). Breastfeeding in the 21st century: Epidemiology, mechanisms, and lifelong effect. The Lancet, Vol. 387, pp. 475-490. https://doi.org/10.1016/S01406736(15)01024-7

[9] Watkins, S., Meltzer-Brody, S., Zolnoun, D., \& Stuebe, A. (2011). Early breastfeeding experiences and postpartum depression. Obstetrics and Gynecology, 118(2), 214-221. https://doi.org/10.1097/AOG.0b013e3182260a2d 
